\title{
Growth and mortality of Serranus cabrilla (Linnaeus, 1758) (Actinopterygii: Perciformes: Serranidae) from Bou Ismail Bay, off Algeria, south-western Mediterranean
}

\author{
FADHILA AILANE, ABDERRAHMANE KASSAR AND FARID HEMIDA \\ Department of Living Resources, National School of Marine Sciences and Coastal Planning - ENSSMAL B. P. 19 \\ 16047, Dely Ibrahim, Algiers, Algeria \\ e-mail: ailane.fadhila35@gmail.com
}

\begin{abstract}
This study was conducted to determine the growth and mortality parameters of the comber Serranus cabrilla (Linnaeus, 1758) in the central region of the Algerian coast. A total of 1568 specimens were collected from January 2016 to April 2018. Total length (TL) varied between 9.3 and $26.2 \mathrm{~cm}$. The maximum total length recorded in the Mediterranean Sea for the species is $26.2 \mathrm{~cm}\left(\mathrm{TL}_{\max }\right)$. The von Bertalanffy growth parameters were estimated using ELEFAN I routine in FiSAT II program $\left(\mathrm{L}_{\infty}=32.80 \mathrm{~cm} ; \mathrm{K}=0.41 \mathrm{yr}^{-1} ; \mathrm{t}_{0}=-0.39 \mathrm{yr}^{-1}\right)$ and those related to the length-weight relationship are as follows: $\mathrm{W}_{\infty}=372.15 \mathrm{~g} ; \mathrm{a}=0.012$ and $\mathrm{b}=2.96\left(\mathrm{r}^{2}=0.93\right)$. Total mortality $(\mathrm{Z})$ and natural mortality $(\mathrm{M})$ coefficients stood at $2.63 \mathrm{yr}^{-1}$ and $0.43 \mathrm{yr}^{-1}$, respectively. The calculated exploitation rate, $\mathrm{E}=0.84$, indicated that $S$. cabrilla population is overexploited.
\end{abstract}

Keywords: Bony fish, Comber, Population dynamics, Serranids, Serranus cabrilla

\section{Introduction}

The comber Serranus cabrilla (Linnaeus, 1758), is a teleost fish of commercial interest, common in the Mediterranean, Western Black Sea and Atlantic Ocean, from the British Isles to the Cape of Good Hope, including the Azores, Madeira and the Canary Islands (Fisher et al., 1987). This species frequents rocky and sandy bottoms and areas with the seagrass Posidonia oceanica. It is found between 0 and $450 \mathrm{~m}$ depth (Carpenter and De Angelis, 2016), but usually only down to $90 \mathrm{~m}$ (Fisher et al., 1987). Most published data are limited to the Atlantic Ocean and the eastern Mediterranean viz., the Canary Islands (Tuset et al., 1996), the Portuguese coasts (Gordo et al., 2016), the southern coasts of Tunisia (Bouain, 1981; Bouain, 1983) and the Turkish coasts (Politou and Papaconstantinou, 1995; Tserpes and Tsimenides, 2001; Turker-Cakir and Torcu-Koc , 2002; Torcu-Koc et al., 2004; Ilhan et al., 2010).

Landings of the comber along the Algerian coast are important since the fifties (Dieuzeide et al., 1959) to the current period. Studies on diet (Rachedi et al., 2018) and growth (Rachedi and Dahel, 2019) have been carried out in the Gulf of Annaba from the eastern Algerian coast, but no studies are available from the central region. The species is heavily exploited by trammel nets and bottom trawl in the Bou Ismail Bay. However, the status of its stock remains unknown. Knowledge of growth and mortality parameters are needed for fitting population dynamics models and for demographic analyses (Khan and Khan, 2014).

The current study provides the first information on some biological parameters of $S$. cabrilla from the Algerian coast of Bou Ismail Bay in the south-west Mediterranean.

\section{Materials and methods}

Study area and sampling

From January 2016 to April 2018, 1568 specimens of $S$. cabrilla were sampled from catches realised off the Bou Ismail Bay. This bay is located in the central part of the Algerian coast, between $36.63^{\circ} \mathrm{N}, 2.40^{\circ} \mathrm{E}$ and $36.80^{\circ} \mathrm{N}, 2.89^{\circ} \mathrm{E}$. It is bounded by the cape of Mount Chenoua from the west and Ras-Acrata from the east (Fig. 1).

For each collected specimen, the total length (TL, in $\mathrm{cm}$ ) and total weight (TW, in $\mathrm{g}$ ) were measured to the nearest $\mathrm{cm}$ and $0.01 \mathrm{~g}$ precision, respectively. S. cabrilla is a simultaneous hermaphrodite species (García-Díaz et al., 1997), which does not allow sex to be determined.

Data analysis

The von Bertalanffy growth parameters were estimated as follows (von Bertalanffy, 1938):

$$
\mathrm{TL}=\mathrm{L}_{\infty} \times\left(1-\mathrm{e}^{-\mathrm{K}}\left(\mathrm{t}-\mathrm{t}_{0}\right)\right)
$$




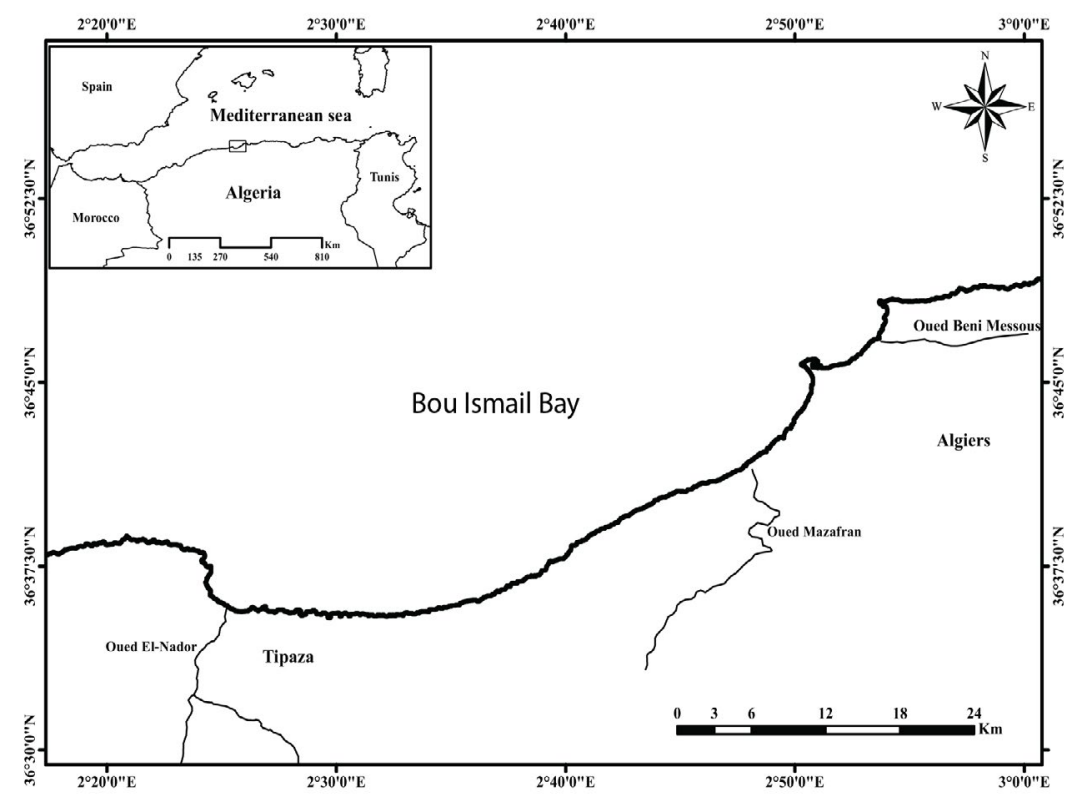

Fig. 1. Bou Ismail Bay on the central coast of Algeria, SW Mediterranean

where TL: fish total length $(\mathrm{cm}) ; \mathrm{L}_{\infty}$ : asymptotic total length $(\mathrm{cm}) ; \mathrm{K}$ : growth coefficient $\left(\mathrm{yr}^{-1}\right)$ and $\mathrm{t}_{0}$ : theoretical age when fish has zero length $\left(\mathrm{yr}^{-1}\right)$.

$\mathrm{L}_{\infty}$ and $\mathrm{K}$ were calculated on the basis of sizefrequency distribution with a class interval of $2 \mathrm{~cm}$ in total length (Fig. 2), using the ELEFAN I routine integrated into FiSAT II program (Gayanilo et al., 2005).

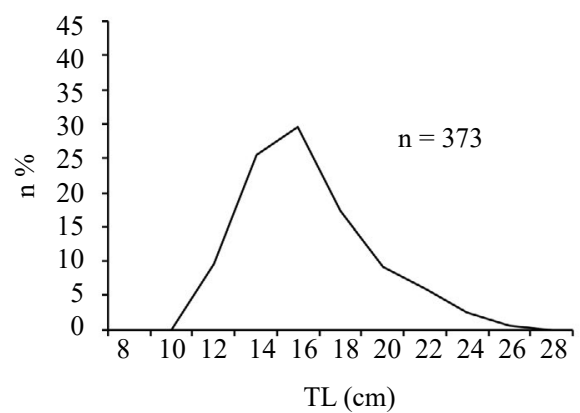

(a)

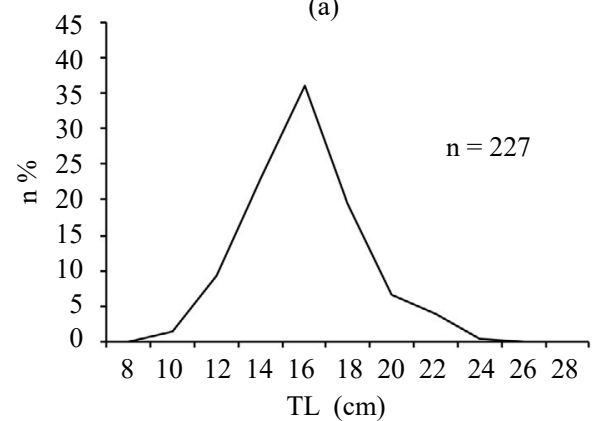

(c)

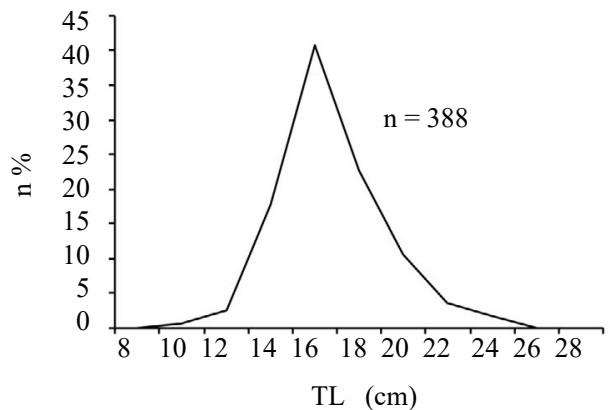

(b)

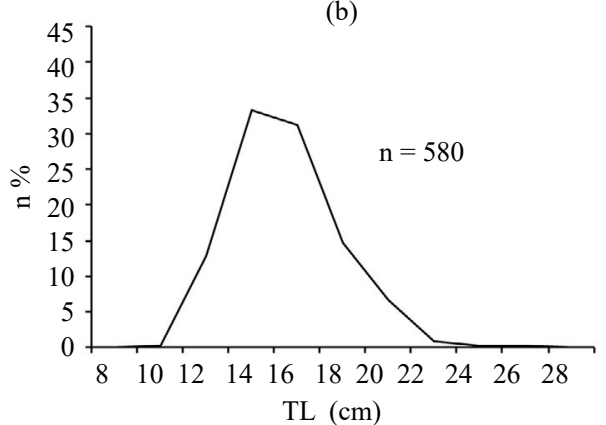

(d)

Fig. 2. Seasonal evolution of size-frequency polygons of $S$. cabrilla in Bou Ismail Bay, SW Mediterranean. (a) Winter; (b) Spring; (c) Summer and (d) Autumn 
The length-weight relationship was established from 1181 data pairs (TL; TW). This relationship in fishes, considered as an allometric growth model (Le Cren, 1951) is written as:

$$
\mathrm{TW}=\mathrm{aTL}{ }^{\mathrm{b}}
$$

where TW: fish total weight (g), TL: fish total length (cm), $\mathrm{b}$ : length-weight factor (slope) and a: constant.

Values of the $b$ factor provide information on fish growth (Froese, 2006): when $b>3$ (positive allometric growth), then there is a significant positive relationship between weight and length which indicates that weight will increase faster with the increase in length.

However, when $b<3$ (negative allometric growth), it indicates that fish grows faster in length than in weight. When $b=3$ (isometric growth), the weight of the fish increases proportionally with length. The null assumption of isometric growth $\left(\mathrm{H}_{0}: \mathrm{b}=3\right)$ was tested by Student's t-test, using the following formula (Schwartz, 1992):

$$
\text { with: } \begin{aligned}
\mathrm{t} & =\frac{[\mathrm{b}-3]}{\mathrm{S}_{\mathrm{b}}} \\
\mathrm{S}_{\mathrm{b}} & =\sqrt{\frac{\left(\frac{\mathrm{S}_{\mathrm{y}}}{\mathrm{S}_{\mathrm{x}}^{2}}-\mathrm{b}^{2}\right.}{\mathrm{n}-2}}
\end{aligned}
$$

where $S_{b}$ is the standard error of the slope for $\alpha=0.05$ to test significant differences among slopes (b and 3 ) between two regressions, $\mathrm{S}_{\mathrm{y}}$ is the standard deviation of the variable $\ln \mathrm{TW}$ and $\mathrm{S}_{\mathrm{x}}$ is the standard deviation of the variable $\ln$ TL.

The instantaneous total mortality rate $(Z)$ was estimated by length converted catch curve method using the FiSAT II program (Gayanilo et al., 2005). Natural mortality (M) was calculated from the empirical formula proposed for the Mediterranean fishes by Djabali et al. (1993):

$$
\begin{aligned}
& \log \mathrm{M}=0.736-0.114 \times \log \mathrm{L}_{\infty}+0.522 \times \log \mathrm{K}- \\
& 0.583 \times \log \mathrm{T}
\end{aligned}
$$

where $\mathrm{L}_{\infty}$ and $\mathrm{K}$ are parameters from the von Bertalanffy equation and $\mathrm{T}$ is the mean annual bottom temperature between 0 and $100 \mathrm{~m}, \mathrm{~T}=18^{\circ} \mathrm{C}$ (MEDAR Group, 2002).

Fishing mortality (F) was obtained with the formula: $\mathrm{F}=\mathrm{Z}-\mathrm{M}$ and the exploitation rate $\mathrm{E}$ was estimated by dividing fishing mortality on total mortality (Z). The exploitation rate indicates whether the stock is underexploited $(\mathrm{E}<0.5)$ or overexploited $(\mathrm{E}>0.5)$, based on the assumption that the stock is optimally exploited when $\mathrm{F}=\mathrm{M}$ or $\mathrm{E}=0.5$ (Gulland, 1971).

\section{Results and discussion}

\section{Growth parameters}

A total of 580 individuals were collected in fall, 388 during spring and 373 in winter. The total length ranged from 9.3 to $26.2 \mathrm{~cm} \mathrm{TL}$ and total weight from 10.34 to $221.56 \mathrm{~g}$. The smallest one was sampled in spring and the largest in winter. Specimens were more abundant in sizes between 14 and $16 \mathrm{~cm}$ TL during most seasons (Fig. 2).

Growth parameters of $S$. cabrilla are shown in Table 1. In Bou Ismail Bay, the values of asymptotic length $\left(\mathrm{L}_{\infty}\right)$ and growth rate $(\mathrm{K})$ were $32.8 \mathrm{~cm}$ and $0.41 \mathrm{yr}^{-1}$, respectively and the value obtained from the growth performance index $\left(\phi^{\prime}\right)$ was $2.64 \mathrm{yr}^{-1}$.

The von Bertalanffy equation determined for $S$. cabrilla is represented by the following formula and its curve is illustrated in Fig. 3.

$$
\mathrm{TL}=32.8\left[1-\mathrm{e}^{(-0.41(\mathrm{t}+0.39))}\right]
$$

Length-weight relationship

The relationship between total length and total weight (Table 2 and Fig. 4) was:

$$
\mathrm{TW}=0.012 \mathrm{TL}^{2.963}
$$

According to the t-test, we observed an isometric growth of this species in Bou Ismail Bay $(b=2.963$;

\begin{tabular}{|c|c|c|c|c|c|c|c|c|}
\hline Authors & Region & $\mathrm{N}^{*}$ & Length range $(\mathrm{cm})$ & $\mathrm{L}_{\infty}^{*}(\mathrm{~cm})$ & $\mathrm{K}^{*}\left(\mathrm{yr}^{-1}\right)$ & $\mathrm{t}_{0}^{*}\left(\mathrm{yr}^{-1}\right)$ & $\phi^{\prime *}\left(\mathrm{yr}^{-1}\right)$ & Method \\
\hline Bouain (1983) & Tunisia & - & - & 31.85 & 0.095 & -1.48 & 1.98 & Scales \\
\hline Tserpes and Tsimenides (2001) & Cretan Shelf Greece & 1004 & $6.3-19.7$ & 22.29 & 0.39 & -0.59 & 2.29 & Otolith \\
\hline Torcu-Koc et al. (2004) & Edremit Bay Turkey & 595 & $8.6-22.3$ & 33.6 & 0.11 & -3.17 & 2.10 & Otolith \\
\hline Ilhan et al. (2010) & Aegean Sea & 1452 & $7.4-22.5$ & 23.88 & 0.298 & -1.58 & 2.23 & Otolith \\
\hline Gordo et al. (2016) & Eastern Atlantic & 471 & $12-26.5$ & 25.26 & 0.21 & -1.72 & 2.13 & Otolith \\
\hline Rachedi and Dahel (2019) & Gulf of Annaba Algeria & 1250 & $11-23.9$ & 24.94 & 0.38 & -0.45 & 2.37 & ELEFAN I \\
\hline This study & Bou Ismaïl Bay & 1568 & $9.3-26.2$ & 32.8 & 0.41 & -0.39 & 2.64 & ELEFAN I \\
\hline
\end{tabular}
$\left.\mathrm{S}_{\mathrm{b}}=0.024 ; \mathrm{r}^{2}=0.93 ; \alpha=0.05 ; \mathrm{t}=1.55<1.96\right)$ : the weight of this fish increased proportionally with its length.

The growth in weight of $S$. cabrilla can be described by the following model:

$$
\mathrm{TW}=372.15\left[1-\mathrm{e}^{-0.41(\mathrm{t}+0.39)}\right]^{2.963}
$$

Table 1. Growth parameters $\left(\mathrm{L}_{\infty}, \mathrm{K}, \mathrm{t}_{0}\right)$ of $S$. cabrilla in the Mediterranean Sea and the Atlantic Ocean

"N: Number of specimens; $\mathrm{L}_{\infty}$ : Asymptotic total length; K: Growth coefficient; $\mathrm{t}_{0}$ : Theoretical age when fish has zero length; $\phi^{\prime}$ : Performance index 


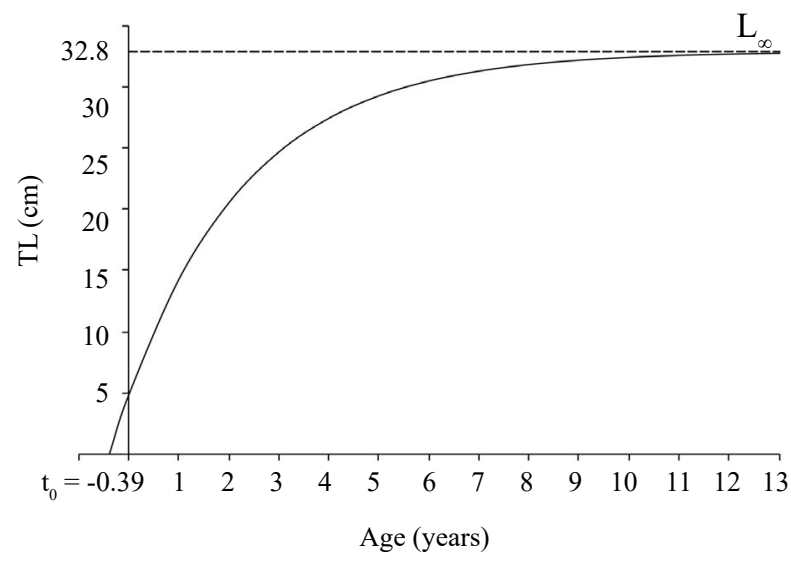

Fig. 3. Estimated mean growth curve in length of $S$. cabrilla in Bou Ismaïl Bay, SW Mediterranean

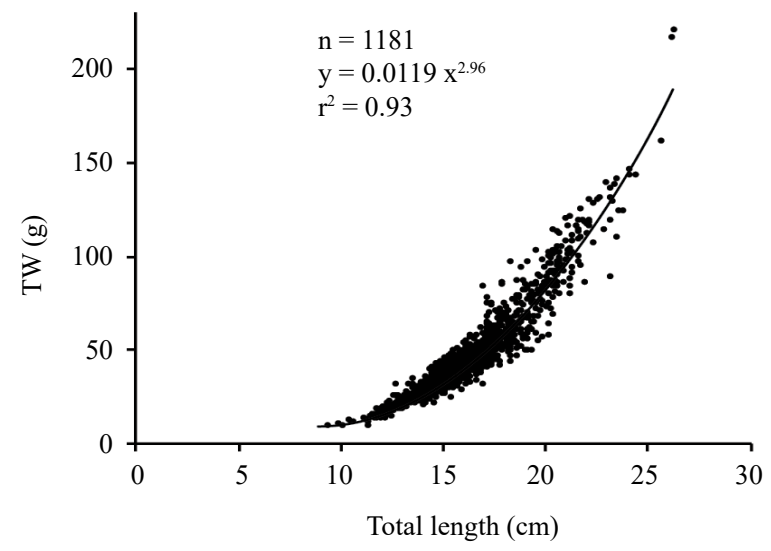

Fig. 4. Length-weight relationship of S. cabrilla from Bou Ismail Bay, SW Mediterranean

Table 2. Length-weight relationship parameters of S. cabrilla in the Mediterranean Sea and the Atlantic Ocean

\begin{tabular}{llllllll}
\hline Authors & Region & $\mathrm{N}^{*}$ & Length range $(\mathrm{cm})$ & $\mathrm{a}^{*}$ & $\mathrm{~b}^{*}$ & $\mathrm{r}^{2}$ & Type \\
\hline Gonçalves et al. (1997) & Portugal & 171 & $12-30.2$ & 0.00007 & 2.66 & 0.91 & Negative allometry \\
Merella et al. (1997) & Balearic Islands & 23 & $7.2-18.6$ & 0.016 & 2.82 & 0.99 & Isometry \\
Moutopoulos and Stergion (2002) & Aegean Sea Greece & 466 & $9.5-25.1$ & 0.01867 & 2.81 & 0.93 & Isometry \\
Torcu-Koc et al. (2004) & Edremit Bay Turkey & 595 & $8.6-22.3$ & 0.0311 & 2.67 & 0.88 & Negative allometry \\
Ilhan et al. (2010) & Aegean Sea Turkey & 1452 & $7.4-22.5$ & 0.0111 & 2.99 & 0.98 & Isometry \\
Ozvarol (2014) & Gulf of Antalya Turkey & 52 & $9-18.5$ & 0.0091 & 3.048 & 0.960 & Positive allometry \\
Gordo et al. (2016) & Eastern Atlantic & 471 & $12-26.5$ & 0.0097 & 3.05 & 0.94 & Isometry \\
Rachedi and Dahel (2019) & Gulf of Annaba Algeria & 1250 & $11-23.9$ & 0.008 & 3.066 & 0.89 & Isometry \\
This study & Bou Ismail Bay & 1181 & $9.3-26.2$ & 0.0119 & 2.96 & 0.93 & Isometry \\
\hline
\end{tabular}

"N: Number of specimens; a: Constant; b: Length-weight factor

\section{Mortality and exploitation rates}

The instantaneous total mortality rate $(\mathrm{Z})$ calculated by the lengths converted catch curve was $2.63 \mathrm{yr}^{-1}$. The value of natural mortality $(\mathrm{M})$ calculated from Djabali's equation (1993) was $0.43 \mathrm{yr}^{-1}$ and the fishing mortality rate was $\mathrm{F}=2.2 \mathrm{yr}^{-1}$. The calculated exploitation rate of the population was $\mathrm{E}=0.84$.

\section{Discussion}

This study is the first of its kind to give results on the growth parameters of $S$. cabrilla from the central coast of Algeria. It was based on length-frequency data which can, provide valuable information on the life history of fish species (Pauly, 1987).

The minimum individual size $(\mathrm{TL}=9.3 \mathrm{~cm})$ is bigger than the minimum size found in the Eastern Mediterranean ( $\mathrm{TL}=6.3 \mathrm{~cm}$; Tserpes and Tsimenides, 2001). The largest measured specimen $(26.2 \mathrm{~cm}$ in TL), is larger than the largest one reported in the Mediterranean, $\mathrm{TL}=25.1 \mathrm{~cm}$ (Moutopoulos and Stergion, 2002); it is the biggest to date in the Mediterranean Sea for the species. However, it is smaller than the Atlantic specimen $(\mathrm{TL}=30.2 \mathrm{~cm})$ reported by Gonçalves et al. (1997).
The von Bertalanffy growth parameters of S. cabrilla estimated by the ELEFAN I method in the Bay of Bou Ismail are quite different from those of the Eastern Mediterranean and the Eastern Atlantic (Table 1), which were based on otolith readings (Tserpes and Tsimenides, 2001; Torcu-Koc et al., 2004; Ilhan et al., 2010 and Gordo et al., 2016).

The estimated asymptotic length was $\mathrm{L}_{\infty}=32.8 \mathrm{~cm}$ and the growth coefficient $\mathrm{K}$ value was $0.41 \mathrm{yr}^{-1}$. Asymptotic length is bigger than the maximum observed size during our survey $(26.2 \mathrm{~cm})$ and bigger than Taylor's approximation (1958 in Pauly, 1984): $\mathrm{TL}_{\max } / 0.95=27.58$ $\mathrm{cm}$. It is close to what was found in the Bay of Edremit by Torcu-Koc et al. (2004) and in the Tunisian coast by Bouain (1983), however it is higher than those calculated by Tserpes and Tsimenides (2001) and Ilhan et al. (2010) in the Eastern Mediterranean; Gordo et al. (2016) in the Atlantic and by Rachedi and Dahel (2019) on the east coast of Algeria (Table 1).

The value of the growth performance index ( $\phi$ ' $\left.=2.64 \mathrm{yr}^{-1}\right)$ is slightly bigger than those found in other regions: 2.13 in the Atlantic Ocean (Gordo et al., 
2016); 2.29 (Tserpes and Tsimenides, 2001) and 2.10 (Torcu-Koc et al., 2004), 2.23 (Ilhan et al., 2010) in the Western Mediterranean. This would indicate that S. cabrilla of the central coast of Algeria grows faster than in the other regions. As for variable minimum and maximum lengths in the different areas, fluctuations in growth parameters $\left(\mathrm{L}_{\infty}, \mathrm{K}\right)$ can be explained by variations in the environmental and the ecological factors (temperature, mortality and food availability) from one area to another (Korcu-Koc et al., 2004).

We must consider that different techniques have been used in the regions studied (Bouain, 1983; Tserpes and Tsimenides, 2001; Torcu-Koc et al., 2004; Ilhan et al., 2010; Gordo et al., 2016). The methodology used in each region also explains the differences between the obtained results.

The allometry coefficient "b" was 2.963. Similar results have been reported by Ilhan et al. (2010) and Moutopoulos and Stergion (2002) in Aegean Sea, by Gordo et al. (2016) in Portugal and by Rachedi and Dahel (2019) in the Gulf of Annaba. Unlike those obtained by Torcu-Koc et al. (2004) in Edremit Bay and by Goncalves et al. (1997) in Portugal, which showed negative allometric growth. Ozvarol (2014) in the Gulf of Antalya presented positive allometric growth for the species (Table 2). In general, the $b$ parameter is subject to changes due to sample size, environmental factors and seasonality (Froese, 2006).

Growth and mortality estimations are important for understanding population dynamics (Ralston and Williams, 1988). We estimated the natural (M) and total mortality (Z) at 0.43 and $2.63 \mathrm{yr}^{-1}$, respectively. The estimated $\mathrm{M}$ value was close to the value obtained in other regions. Gordo et al. (2016) reported a total mortality rate between 0.44 and $0.48 \mathrm{yr}^{-1}$ in the eastern Atlantic (Portugal), Tserpes and Tsimenides (2001) reported $0.35 \mathrm{yr}^{-1}$ at the Cretan Shelf (Greece) and Torcu-Koc et al. (2004) obtained $0.32 \mathrm{yr}^{-1}$ in Edremit Bay (Turkey). On the other hand, the value of natural mortality $\left(\mathrm{M}=0.81 \mathrm{yr}^{-1}\right)$ obtained by Rachedi and Dahel (2019) in the Gulf of Annaba was higher than the value obtained in this study. In fact, according to Sparre and Venema (1996) values of natural mortality coefficients for the same species may be different in distinct areas, depending on the density of predators and competitors whose abundance is otherwise influenced by fishing activities. Even small changes in growth parameters could seriously affect the calculated mortality (Tserpes and Tsimenides, 2001).

The resulting exploitation rate, $\mathrm{E}=0.84$, is higher than the optimal value (0.5) mentioned by Gulland (1971). Hence, the comber stock of this species is overexploited in the study region. This situation could have an impact on recruitment if individuals are caught during the reproduction period (Sossoukpe et al., 2013).

Our study was carried out in order to estimate the growth and the exploitation parameters of the comber S. cabrilla from Bou Ismail Bay, Algeria. The determined parameters are necessary for the stock assessment and management of this species in the central coast of Algeria. The inshore fishery for the comber S. cabrilla in Bou Ismail Bay targets mainly individuals between 14 and $16 \mathrm{~cm}$ in total length $(59.95 \%)$, while larger $(24-26 \mathrm{~cm})$ and smaller individuals $(9-11 \mathrm{~cm})$ are caught in smaller proportions $(1.66 \%)$. The length-weight relationship of this species shows that growth in length and weight is isometric $\left(\mathrm{a}=0.0119, \mathrm{~b}=2.96, \mathrm{r}^{2}=0.93\right)$. The calculated exploitation rate $(E=0.84)$ reflects a possible overfishing situation. The situation is alarming and the authorities must act immediately in order to preserve the species in the central coast of Algeria.

\section{Acknowledgments}

The authors are deeply indebted to all those who helped in collection of fish samples.

\section{References}

Bouain, A. 1981. Serranus (Teleostei: Serranidae) of the southern coasts of Tunisia; size at first maturity, reproduction period. Cybium, 5(4): 65-75 (In French).

Bouain, A. 1983. Linear growth of Serranus on the southern coast of Tunisia. Report of the International Commission for the Scientific Exploration of the Mediterranean Sea, 28(5): 87-91 (In French).

Carpenter, K. E. and De Angelis, N. 2016. The living marine resources of the Eastern Central Atlantic, vol. 4: Bony fishes, part 2 (Perciformes to Ttradontiformes) and sea turtles. FAO species identification guide for fishery purposes, Food and Agriculture Organisation of the United Nations, Rome, Italy, p. 2343-3124.

Dieuzeide, R., Novella, M. and Rolland, J. 1959. Catalog of fish from the Algerian coasts, vol. II: Osteopterygiens. Bulletin of the work of the Castiglione aquaculture and fishing station, Algers, 299 pp. (In French).

Djabali, F., Mehailia, A., Koudil, M. and Brahmi, B. 1993. Empirical equations for the estimation of natural mortality in Mediterranean teleosts. NAGA, ICLARM Q., 16(1): 35-37.

Fisher, W., Bauchot, M. L. and Schneider, M. 1987. FAO Species identification sheets for fishing needs (Revision 1), Mediterranean and Black Sea, Fishing zone 37, vol. II: Vertebrates. Food and Agriculture Organisation of the United Nations, Rome, Italy, p. 760-1530 (In French).

Froese, R. 2006. Cube law, condition factor and weight-length relationships: History, meta-analysis and recommendations. J. Appl. Ichthyol., 22(4): 241-253. Doi:10.1111/j.1439-04 26.2006.00805.x. 
García-Díaz, M. M., Tuset, V. M., Gonzalez, J. A. and Socorro, J. 1997. Sex and reproductive aspects in Serranus cabrilla (Osteichthyes: Serranidae): Macroscopic and histological approaches. Mar. Biol., 127(3): 379-386. Doi: 10.1007/ s002270050024.

Gayanilo, J. F. C., Sparre, P. and Pauly, D. 2005. The FAO-ICLARM stock assessment tools (FiSAT) user's guide, FAO computerised information series (Fisheries). Food and Agriculture Organisation of the United Nations, Rome, Italy, $168 \mathrm{pp}$.

Goncalves, J. M. S., Bentes, L., Lino, P. G., Ribeiro, J., Canario, A. V. M. and Erzini, K. 1997. Weight-length relationship for selected fish species of the small scale demersal fisheries of the south and south-west coast of Portugal. Fish. Res., 30(3): 253-256. Doi: 10.1016/s0165-7836(96)00569-3.

Gordo, L. S., Neves, A., Vierira, A. R., Paiva, R. B. and Sequeira, V. 2016. Age, growth and mortality of the comber Serranus cabrilla (Linnaeus, 1758) in the Eastern Atlantic. Mar. Biol. Res., 12(6): 656-662. Doi: 10.1080/17451000.2016.1169295.

Gulland, J. A. 1971. The fish resources of the oceans. Fishing News Books Ltd., Surrey, UK, 225 pp.

Ilhan, D., Akalin, S., Tosunoglu, Z. and Ozaydin, O. 2010. Growth characteristics and reproduction of comber, Serranus cabrilla (Actinopterygii, Perciformes, Serranidae), in the Aegean Sea. Acta. Ichthyol. Piscat., 40(1): 55-60. Doi: 10.3750/AIP2010.40.1.07.

Khan, S. and Khan, M. A. 2014. Importance of age and growth studies in fisheries management. In: National Seminar "Next Generation Sciences: Vision 2020 and Beyond", 8 March 2014, Maharshi Dayanand University, Rohtak, Haryana, India, p.194-201.

Le Cren, E. D. 1951. The length-weight relationship and seasonal cycle in gonad weight and condition in the perch (Perca fluviatilis). J. Anim. Ecol., 20(2): 201-219. Doi: 10.2307/1540.

MEDAR Group 2002. Mediterranean and Black Sea database of temperature salinity and biochemical parameters. Climatological Atlas. French Research Institute for the Exploitation of the Sea (IFREMER) and National Institute of Oceanography and Experimental Geophysics (OGS) (4 CD-ROMs).

Merella, P., Quetglas, A., Alemany, F. and Carbone, A. 1997. Length-weight relationship of fishes and cephalopods from the Balearic islands (Western Mediterranean). NAGA, ICLARM Q., 20(3-4): 66-68.

Moutopoulos, D. K. and Stergiou, K. I. 2002. Length-weight and length-length relationships of fish species from the Aegean Sea (Greece). J. Appl. Ichthyol., 18(3): 200-203. Doi: 10.1046/j.1439-0426.2002.00281.x.

Munro, J. L. and Pauly, D. 1983. A simple method for comparing the growth of fishes and invertebrates. Fishbyte, 1(1): 5-6.
Ozvarol, Y. 2014. Length-weight relationships of 14 fish species from the Gulf of Antalya (north-eastern Mediterranean Sea, Turkey). Turkish J. Zool., 38: 342-346. Doi: 10.3906/ zoo-1308-44.

Pauly, D. 1983. Some simple methods for the assessment of tropical fish stocks. FAO Fish. Tech. Pap., 234: 1-52.

Pauly, D. 1984. Fish population dynamics in tropical waters: a manual for use with programmable calculator. International Centre for Living Aquatic Resources Management, Manila, Philippines, $325 \mathrm{pp}$.

Pauly, D. 1987. A review of the ELEFAN system for analysis of length-frequency data in fish and aquatic invertebrates. In: Pauly, D. and Morgan, G. R. (Eds.), Length-based methods in fisheries research. ICLARM Conference Proceedings 13. International Centre for Living Aquatic Resources Management, Manila, Philippines, p. 7-34.

Politou, C. Y. and Papaconstantinou, C. 1995. Age and growth of comber, Serranus cabrilla (L., 1785) in the Thracian Sea and the Thermaikos Gulf (Northern Greece). Report of the International Commission for the Scientific Exploration of the Mediterranean Sea, 34 pp.

Rachedi, M., Derbal, F. and Kara, M. H. 2018. Feeding habits of the comber Serranus cabrilla (Linnaeus, 1758) (Teleostei, Serranidae) from the gulf of Annaba (Eastern coast of Algeria). Cah. Biol. Mar., 59: 149-158. Doi: 10.21411/ CBM.A.7B25A05C.

Rachedi, M. and Dahel, A. T. 2019. Population dynamic parameters of the comber Serranus cabrilla (Teleostei, Serranidae) in Western Mediterranean (Eastern Coast of Algeria). Egyptian J. Aqua. Biol. Fish., 23(5): 31- 42. Doi: 10.21608/EJABF.2019.64840.

Ralston, S. V. and Williams, H. A. 1988. Depth distributions, growth and mortality of deep slope fishes from the Mariana Archipelago. NOAA-Technical Memorandum, NMFSSWFC, 113, p. 1-47.

Schwartz, D. 1992. Statistical methods for the use by physicians and biologists, $3^{\text {rd }}$ and $15^{\text {th }}$ edn, Flammarion Medicine and Science, Paris, France, 306 pp (In French).

Sossoukpe, E., Nunoo, F. K. E., Ofori-Danson, P. K., Fiogbea, E. D. and Dankwa, H. R. 2013. Growth and mortality parameters of $P$. senegalensis and $P$. typus (Sciaenidae) in nearshore waters of Benin (West Africa) and their implications for management and conservation, J. Fish. Res., 137: 71-80. Doi: 10.1016/j.fishres.2012.08.020.

Sparre, P. and Venema, S. C. 1996. Introduction to tropical fish stock assessment (part one: manual). FAO Fisheries Technical Paper 306/1. Rev. 1, Food and Agriculture Organisation of the United Nations, Rome, Italy, 401 pp.

Torcu-Koc, H., Turker-Cakır, D. and Dulcic, J. 2004. Age, growth and mortality of the comber, Serranus cabrilla (Serranidae) in the Edremit Bay (NW Aegean Sea, Turkey). Cybium, 28(1): 19-25. 
Tserpes, G. and Tsimenidis, N. 2001. Age, growth and mortality of Serranus cabrilla (Linnaeus, 1785) on the Cretan shelf. Fish. Res., 51(1): 27-34. Doi: 10.1016/s0165-7836(00)00237-x.

Turker-Cakir, D. and Torcu-Koc, H. 2002. Feeding habits of Serranus cabrilla (Serranidae) in Edrerrit Bay (North Aegean Sea). Pakistan J. Biol. Sci., 5(10): 1131-1134. Doi: 10.3923/pjbs.2002.1131.1134.
Tuset, V. M., Gonzalez, J. A., García-Díaz, M. M. and Santana, J. I. 1996. Feeding habits of Serranus cabrilla (Serranidae) in the Canary Islands. Cybium, 20(2): 161-167.

Von Bertalanffy, L. 1938. A quantitative theory of organic growth (inquiries on growth laws. II). Human Biol., 10(2): 181-213. 